\title{
THE EFFECT OF BRAND TRUST AND BRAND IMAGE TOWARD UNIVERSITY SELECTION
}

\author{
Intan Tenisia Prawita Sari¹, Evi Sylvia ${ }^{2}$ \\ Universitas Garut, Indonesia*12 \\ intantenisia@uniga.ac.id*1
}

\begin{abstract}
Universities must respond to the competition to attract new students. The purpose of this study was to test and analyze how brand trust and brand image on decision making in university selection at Garut Regency. Descriptive analysis methods are used for responses and path analysis methods are used for the hypothetical test. To test the research instrument is used validity and reliability tests, then to change the data in the ordinal form to interval data using the Method of Successive Interval. The results showed that the respondents' responses indicated that the brand image and brand trust of universities in Garut Regency were very good. Furthermore, the variables of brand trust and brand image have a simultaneous and partial influence on the variable of choosing decisions. Then the variable that had the greatest influence on the decision to choose a campus in Garut Regency was the brand image variable followed by the brand trust variable.
\end{abstract}

Keywords: Student, University, Brand Trust, Brand Image, Decision Making

\section{INTRODUCTION}

Currently, higher education development has changed rapidly. This is shown by the escalation number of higher education institutions, both public and private education organizations. Thus, leads to competition in reaching consumers who are prospective students who have to choose the institution where they want to study. According to (Rahmawati, 2013) students are consumers of a college or university institution. However, the University's decision making is still volatile and difficult to predict. (Reinartz et al., 2004) explained that consumer preferences often change so that each institution, including universities, is required to be able to follow changes in consumer preferences continuously.

This phenomenon also occurs in universities in Garut Regency. There are 14 universities in Garut Regency, namely 1 state university that is Padjadjaran University, 9 private universities under LLDIKTI IV, and 4 private universities under the Ministry of Religion. The universities are competing to find new students as consumers. Based on the ranking of the best universities in Indonesia based on webometrics in 2020, it is known that the top university rankings are Garut University at 254, STT Garut rank 277, AMIK Garut rank 654 and other universities are in the 1000s. Padjadjaran University ranking was not included because UNPAD only has one study program located in Garut Regency, namely the nursing study program.

Meanwhile, the number of Garut's high school students in 2020 is 122,931 pupils consisting of 58,826 vocational school students, 41,156 high school students, and 22,949 MA students. A large number of students is an opportunity for the universities to attract as many new students at universities in Garut Regency and minimize these students from choosing other universities outside Garut Regency.

Furthermore, in attracting the interest of prospective college students, the university must have a high selling value by creating a good image and creating a trust for the good. According to (Neupane, 2015), a strong and positive brand image can maintain consumer satisfaction and retain existing ones. The positive image of the 
University will create a better opportunity to attract students from all corners of the country.

According to (Setiadi, 2013), an image is the total perception of an object, which is formed by processing information from various sources at any time. Thus, image is very important for the University to shape the perception of the wide community, especially potential customers before they make a decision. Some people has a good image of perception towards a particular university, while other people have a poor image on the perception of the same university. Differences in the perception of a particular object are possible because each individual has different experiences, understandings, and ways of capturing information. A good image leads to the perception of a quality product so that customers will easily forgive a mistake the first time (Rangkuti, 2013).

Furthermore, the image that universities need to build is brand trust and brand image. According to (Lau \& Lee, 1999), brand trust is the willingness of consumers to trust the brand at all costs due to the expectations of the brand and providing positive results for consumers. (Ferrinadewi, 2008) stated the important activities that need to do by the company to achieve customer trust that is achieving the results, Acting with integrity, demonstrated concern, and level of trust.

Achieving the results have a meaningful expectation of consumers are the promises that must to fulfilled by the company. Acting with integrity means the company must consistent in action to fulfill the promised in any circumstances. A demonstrated concern means that the company must have an ability to understand the consumer's struggles in consuming products, and last, the Level of trust has meaning to measure the three steps done by the company. While, (Kotler \& Keller, 2012) affirm brand trust has four indicators namely benevolence, ability, integrity, and Willingness to depend.

Brand image is the result of a consumer's outlook or research on a brand, it is good or bad. This view is based on their consideration or selection by comparing the differences between several brands so that the brand offer fit with their needs will be selected. A strong and positive image is one of the important things. The important goal of having a brand image is to create a clear and appropriate message to consumers. A strong brand can create good and long-term brand loyalty that allows consumers to see the product as a good product (Pertiwi et al., 2017) Brand image has three supporting variables (Xian et al., 2011) namely: (1) Corporate image is the image that exists in the company itself. The company as an organization tries to build its image with the aim of none other to enhance the company name so that it will influence everything about what the company does; (2) User image is a set of characteristics of consumers associated with the typical characteristics of brand's consumers, the image of the user can be formed directly from the experience and contact with the user of the brand; (3) Product image, consumer image of a product that can have a positive or negative impact related to consumer needs, wants and expectations. Furthermore, (Keller, 2003) supporting factors for the formation of brand image in brand associations: (1) Favorability of brand association One of the factors forming a brand image is the superiority of the product, where the product is superior in competition. According to (Russel \& Lane, 1996), there is a need, a desire, and a demand which is something to fulfill the brand's needs; (2) Strength of brand association: Strength of brand association is the strength of brand association and depends on how information is entered into the consumer's memory and how the process survives as part of the brand 
image. According to Stanton quoted by (Saladin, 2006), a promotion mix is a combination of face-to-face sales, advertising, sales promotion, publicity, and relationships that help achieve sales goals; (3) Uniqueness of brand association: Uniqueness of brand association is an association of a brand that inevitably has to compete which can be used as a reason for consumers to choose a particular brand, by positioning the brand more towards experiencing or benefiting from the product image.

(Peter \& Olson, 2010) define purchasing decision making as follows: the core process in consumer decision making is an integration process used to combine knowledge to evaluate two or more alternative behaviors. The result of the integration process is a choice, cognitively showing behavioral intentions. (Kotler \& Keller, 2012) suggest that the purchasing decisionmaking process through five stages, that is: (1) Introduction to the problem: The buying process begins when the buyer recognizes a problem or need that is triggered by an internal or external stimulus; (2) Information seekers: Consumers who are aroused by their needs that motivate to seek more information. We can distinguish between the two levels of engagement with a search. The lower state of search is called incisive attention. At this level, a person only becomes more receptive to information about a product. At the next level, one can enter active information search: search for reading material, call friends, do online activities, and visit stores to learn about the product; (3) Evaluation of alternatives: At this stage, the consumer forms a conscious and rational assessment of the product. Several basic concepts will help to understand the evaluation process, such as a. Consumers try to satisfy a need. b. Consumers are looking for certain benefits from product solutions. Consumers see a product as a group of attributes with various abilities to deliver the benefits needed to satisfy that need. (4) Purchase decision: At this stage, consumers form preferences between brands in a collection of choices; (5) Post-purchase behavior: After purchasing a product, consumers may experience conflicts overseeing certain worrying features or hearing pleasant things about other brands and being alert to information that supports the decision;

Based on the research background, the authors identify the research problem statement as follows: "There is no study among students in Garut Regency how the influence of brand trust and brand image on decision making to choose a university". In connection with the problem statement above, the authors formulate the main problem questions of this study are: "How is the influence of service quality, trust and brand image on university selection decision making".

The research objective was to obtain data that will be used to test and analyze how brand trust and brand image towards decision making in university selection at universities throughout Garut Regency.

\section{METHODS}

The method in this research is descriptive associative. The associative descriptive method is a method that serves to provide an overview of the object under study through sample or population data as it is, then an analysis is carried out to see the relationship between the two independent variables on the dependent variable and generally accepted conclusions are made.

Meanwhile, to obtain data and information, the authors used survey techniques, namely the collection of information through field data and documentation describing related factors. Flowcharts are used to help problem-solving analysis described in Figure 1. as follows: 


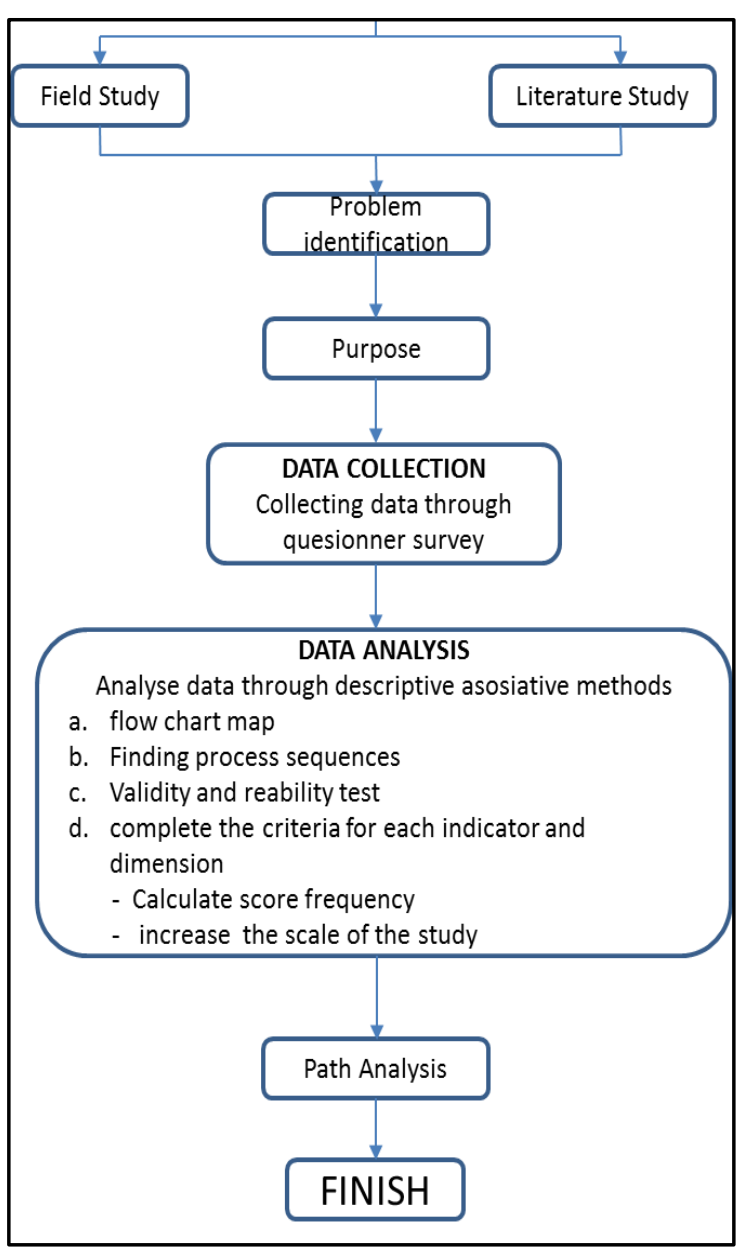

Figure 1. Research Flow Chart

Source: data that has been processed by the author (2020)

There are 2 independent variables used in this research namely: (1) Brand image, which is favorability of brand, the strength of associations, uniqueness of brand associations; (2) Brand trust, which are benevolence, ability, integrity dan willingness to defense.

The sample selection was carried out using a non-probability sampling method using the purposive sampling technique. According to (Singarimbun \& Effendi, 1989), purposive sampling is a method of samples taking that are not random and based on certain considerations. The sample selection is based on the consideration that this can represent the student population in all tertiary institutions in Garut Regency. Furthermore, the length of the research was carried out for 9 months, from January to September 2020.

The data collection technique was used as a questionnaire tool. The response form of the questionnaire is given in a closed and multiple choices form. The use of questionnaires is based on considerations such as limited time, cost, and a large enough sample size. Also, selected sample respondents can read and understand the content of each proposed instrument.

The next step of this research is to test the research tool by carrying out several phases before analyzing the data. The tests are validity and reliability. According to Ghozali and Fuad (2005), the validity test is a test that aims to determine the ability of an indicator to measure latent variables. While the reliability test is a test to determine the consistency of measurement indicators from a latent variable.

Then, the calculation of the frequency score is used to describe the research variables. The percentage of answer scores is used to determine and interpret the tendency of respondents' answers to each indicator and variable dimension. Collecting data through a five option scale questionnaire, resulting from data on an ordinal scale. For further analysis, especially the use of Path Analysis, the data in the form of an ordinal scale must be upgraded to an interval scale.

Meanwhile, the research hypothesis which will be tested by t-test is as follows.

$\mathrm{HO}$ : There is no relationship between brand trust and brand image with decision making

$\mathrm{H} 1$ : There is a relationship between brand trust and brand image with decision making

The basis for the F-Test decision making is based on (1) Comparison of the chi-squared count with a chisquared table: (a) If chi-squared count 
$<$ chi squared table, then $\mathrm{Ho}$ is accepted, (b) If khi squared count $>$ chisquared table, then Ho is rejected; (2) Opportunity (significance): (a) If the odds $>0.05$, then Ho is accepted, (b) If the odds $<0.05$, then $\mathrm{Ho}$ is rejected.

\section{RESULTS AND DISCUSSION Respondent Description}

The characteristics of the respondents in this study were the origin of the university, gender, and semester that had been taken. The distribution of respondents can be seen in table 1.

Tabel. 1. Respondent Characteristics based on University Origin

\begin{tabular}{|c|c|c|c|c|}
\hline No & $\begin{array}{c}\text { University } \\
\text { Origin }\end{array}$ & $\begin{array}{l}\text { T } \\
\text { Resp } \\
\text { Male }\end{array}$ & $\begin{array}{l}\text { tal } \\
\text { ondent } \\
\text { Female }\end{array}$ & (\%) \\
\hline 1 & $\begin{array}{l}\text { Universitas } \\
\text { Garut }\end{array}$ & 8 & 12 & 20 \\
\hline 2 & STTG & 7 & 4 & 11 \\
\hline 3 & IPI Garut & 7 & 10 & 17 \\
\hline 4 & AMIK Garut & 6 & 1 & 7 \\
\hline 5 & $\begin{array}{l}\text { STIE Yasa } \\
\text { Anggana }\end{array}$ & 3 & 6 & 9 \\
\hline 6 & STH Garut & 4 & 2 & 6 \\
\hline 7 & $\begin{array}{l}\text { Akper Karsa } \\
\text { Husada }\end{array}$ & 2 & 8 & 10 \\
\hline 8 & $\begin{array}{l}\text { Universitas } \\
\text { Bhakti } \\
\text { Husada }\end{array}$ & 2 & 3 & 5 \\
\hline 9 & $\begin{array}{l}\text { STIA Darul } \\
\text { Arqam }\end{array}$ & 4 & 4 & 8 \\
\hline 10 & $\begin{array}{l}\text { STIA Persis } \\
\text { TOTAL }\end{array}$ & $\begin{array}{c}3 \\
46 \\
\end{array}$ & $\begin{array}{c}4 \\
54 \\
\end{array}$ & $\begin{array}{c}7 \\
100 \\
\end{array}$ \\
\hline
\end{tabular}

Source: data that has been processed by the author (2020)

The results of the correspondent data show that there are no respondents who dominate gender, even though the number of female respondents is $8 \%$ higher than male. Meanwhile, based on the origin of the university, it was found that respondents from the University of Garut and IPI Garut were at most, respectively, as many as $20 \%$ and $17 \%$. This is quite normal where the number of students from the two universities is higher than other universities.

Tabel. 2. Respondent Characteristics based on Length Study

\begin{tabular}{|c|c|c|c|}
\hline No & $\begin{array}{c}\text { University } \\
\text { Origin }\end{array}$ & $\begin{array}{c}\text { Responde } \\
\text { nt }\end{array}$ & Percentage \\
\hline 1 & Semester 2 & 14 & 14 \\
\hline 2 & Semester 4 & 16 & 16 \\
\hline 3 & Semester 6 & 28 & 28 \\
\hline 4 & Semester 8 & 37 & 37 \\
\hline 5 & > Semester 8 & 5 & 5 \\
\hline & TOTAL & 100 & 100 \\
\hline
\end{tabular}

Furthermore, the characteristics of the respondents based on the length of the study show that students in Semesters 8 and 6 are the most who filled questionnaires with $37 \%$ and $28 \%$. This is understandable because those who still come to campus are final students who manage their thesis to the academic department, while students under them are still studying online due to the Covid-19 pandemic and the closure of several universities. The average answer criteria of respondents are calculated based on calculations

$$
\frac{n \max -\text { nmin }}{n \max }=\frac{5-1}{5}=0,8
$$

So, it is known that the answer range is 0.8 and the criteria for the respondent's answer range are as follows:

Tabel. 3. Answer Average Criteria of Respondent

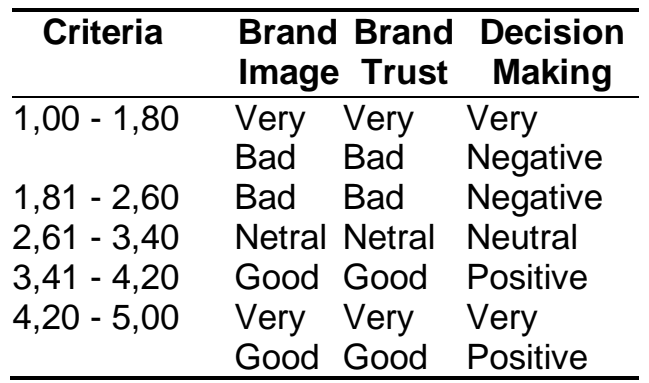

Source: data that has been processed by the author (2020) 
The range of the mean of answers is used to assess the questionnaire. Furthermore, the results of the descriptive analysis are shown as follows:

Table. 4. Results of Respondents' Responses

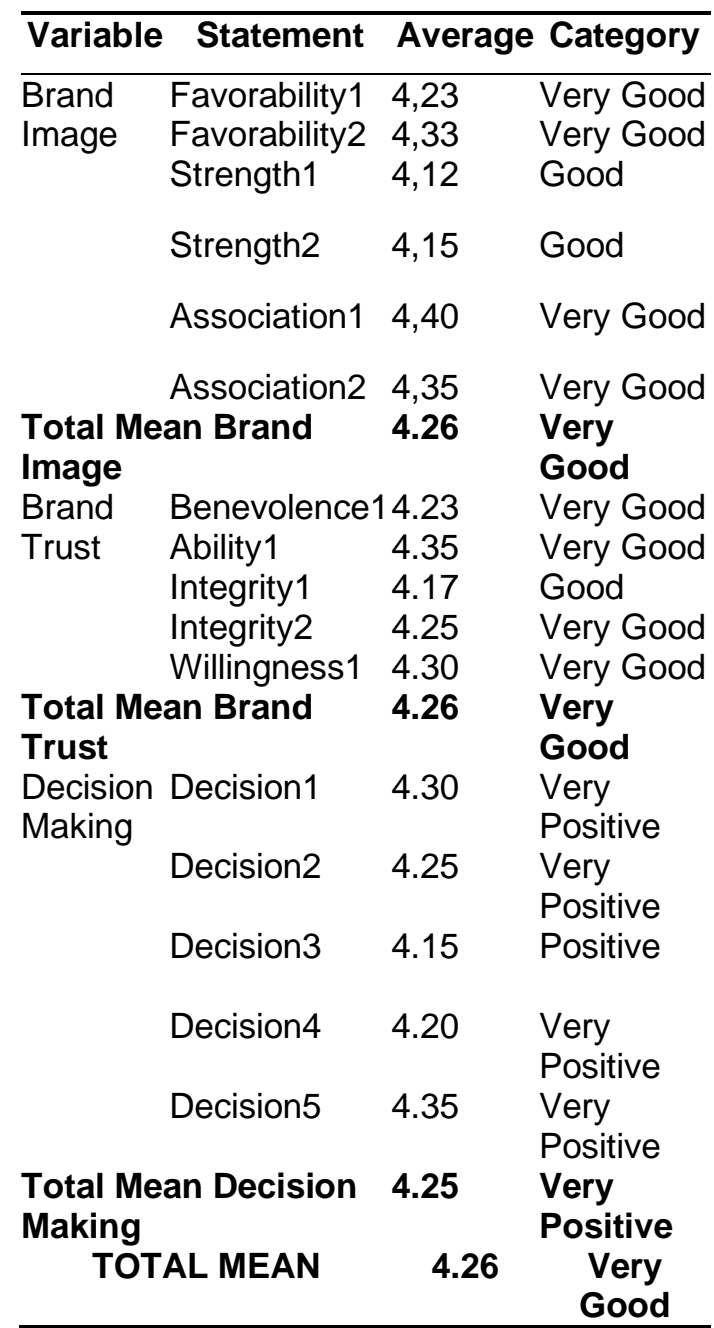

Source: data that has been processed by the author (2020)

From the respondents' responses data, it is known that the brand image of universities in Garut Regency is very good, since its average value reaches 4.26. The same thing happened to the brand trust variable which had an average score of 4.26 so that consumers believed in the image of higher education institutions in Garut Regency. This also applies, to choosing a university where they can decide to choose a university in Garut as a place to continue their studies with a very positive score of 4.25 .

\section{Validity dan Reability Test}

The calculation in the validity test uses SPSS 25.0 software. The validity test data is shown in table 5 .

Tabel. 5. Validity Test

\begin{tabular}{lllll}
\hline \multicolumn{2}{l}{ Variable Item } & \multicolumn{2}{l}{ r-countr-table } & $\begin{array}{l}\text { Explanat } \\
\text { ion }\end{array}$ \\
\hline Brand & Fav1 & 6,34 & 0,195 & Valid \\
Image & Fav2 & 5,98 & 0,195 & Valid \\
& Str1 & 6,39 & 0,195 & Valid \\
& Str2 & 7,05 & 0,195 & Valid \\
& Ass1 & 6,11 & 0,195 & Valid \\
& Ass2 & 5,87 & 0,195 & Valid \\
Brand & Ben1 & 6.23 & 0,195 & Valid \\
Trust & Abi1 & 6.35 & 0,195 & Valid \\
& Int1 & 6.17 & 0,195 & Valid \\
& Int2 & 5.95 & 0,195 & Valid \\
& Wi1 & 6.30 & 0,195 & Valid \\
& Dec1 & 6.30 & 0,195 & Valid \\
Dec2 & 6.25 & 0,195 & Valid \\
Decision & Dec3 & 6.15 & 0,195 & Valid \\
Making & Dec & & & \\
& Dec4 & 6.20 & 0,195 & Valid \\
& Dec5 & 6.35 & 0,195 & Valid \\
\hline
\end{tabular}

Source: data that has been processed by the author (2020)

In this test, the $95 \%$ significance standard is used and the r-table value is known as 0.195. Meanwhile, the results of the calculation have various values, but all values exceed the $r$ table. This value is in accordance with the rules according to (Santoso, 2010) where if $r$ count $>r$ table, all data are valid. This means that the data collected by researchers is precise and accurate in accordance with proper and accountable rules and standards.

Furthermore, the reliability test was carried out. The results show that all variables can be considered reliable. 
Cronbach's alpha value for brand image variable is 0.765 , brand trust is 0.734 , and decision making is 0.764 . This is in accordance with the theory presented by Nunally (1967) in (Sugiyono, 2013) where the research variable can be considered realistic if it has a Cronbach Alpha value> 0.6. So, The variables in this study are reliable and they are worthy of being a research measuring tool.

\section{Multiple Linear Regression Analysis}

The confidence interval used in multiple linear regression analysis is $95 \%$. The results of the analysis found the following equation:

$$
y=0,747+0,445 X_{1}+0,396 X_{2}
$$

This equation can be defined as follow: $\alpha=$ The decision to choose a university will be constant at a value of 0.747 if it is not influenced by brand trust and brand image variables.

$\beta 1=$ The decision to select a university will increase by 0.445 if the brand image variable increases by $1 \%$. On the other hand, if the brand image variable decreases by $1 \%$, the decision to choose a university will decrease by 0.445 also.

$\beta 2=$ The decision to select a university will increase by 0.396 if the brand trust variable increases by $1 \%$. Vice versa, if the brand trust variable decreases by $1 \%$, the decision-making also will decrease by 0.396 .

\section{Hypothetical Test}

The hypothetical test is held in 2 ways, namely partial and simultaneous test. Simultaneous test analysis using the $\mathrm{F}$ test and the results are shown in Table 6

Table. 6. Simultaneous test analysis

\begin{tabular}{lccccc}
\hline \multicolumn{1}{c}{ Model } & Sum of Square & $\mathbf{d f}$ & $\begin{array}{c}\text { Mean } \\
\text { Square }\end{array}$ & $\mathbf{f}$ & Sig. \\
\hline Regressio & 842,875 & 2 & 421,438 & 108,758 & 0,00 \\
$\mathrm{n}$ & & & & & \\
Residual & 375,855 & 97 & 3,875 & & \\
Total & $1,218,730$ & 99 & & & \\
\hline
\end{tabular}

Source: data that has been processed by the author (2020)

Based on the results of the f-test, it is known that the value of $f$-count> $f$ table is $73.742>2.71$ and the $p$-value is $0.000<0.05$. Therefore, it can be concluded that the independent variable brand trust $(\mathrm{X} 1)$, brand image (X2) together have a positive and significant effect on the decision to choose a university in Garut Regency. So the first hypothesis which states that "It is suspected that the variables Brand Trust and Brand Image have a positive and significant effect together on the decision to choose a university campus in Garut Regency" is rejected. Then, to determine the partial effect, the t-test was carried out. The test results show that the t-count of the brand trust variable (X2) has a t-count of $3,972>1,66088$, which means that the brand trust variable can be said to have had a positive influence on the decision to choose. The $p$-value is $0,000<0.05$ which means significant. Partially, the brand trust variable has a positive effect. Then, the variable brand image (X1) has a t-count of 5.327> 1.66088 which means that the brand image variable can be said to have had a positive influence on the decision to choose. The $p$-value $0.000<0.05$ which means it is significant. Partially, brand trust and brand image variable have a positive effect.

To find out the level of contribution given by brand trust and 
brand image to the decision making can be known through the determination test $(\mathrm{R} 2)$. It can be seen that the adjusted $R$ square has a value of 0.695 . This means that the advertising variables, brand trust, and brand image contribute to the decision to choose by $69.5 \%$ and the remaining $30.5 \%$ is influenced by other factors that are not examined.

The partial test results of the brand image variable showed a positive and significant influence on the decision to choose a university is in accordance with the research that had been done previously. The research result of (Desy, 2016) with the title the influence of a brand image, location and facilities on student decisions to choose Pancabudi University concluded that brand image has a big influence with a percentage contribution of $37.3 \%$. (Rangkuti, 2013) said that a wellformed brand image will have a positive impact on the company, which is to convince consumers to get quality and consistency when buying a product and it is also will increase consumer motivation to make purchases or make choices.

The same result on brand trust shows that brand trust give a positive and significant influence on the decision to choose a college in Garut Regency. The results of this study are in line with the research of (Fianto, 2014) with the title of the journal "The Influence of Brand Image on Purchase Behaviour Through Brand Trust". This research concluded that brand trust has a strong influence on the willingness to decisions making. Trust will also arise due to the willingness of consumers to trust and believe in the brand. (Lau \& Lee, 1999) argue that brand trust is the willingness of consumers to trust the brand with all the risks because of the expectations promised by the brand in providing positive results for consumers. Therefore, the brand also plays an important role in becoming the identity of the product. A brand must be able to give confidence to consumers that its brand can truly be trusted. With the construction of a brand trust by Universities in Garut Regency, the public or students will increasingly believe that the policies issued by the campus will be able to meet their needs and desires.

\section{CONCLUSION}

Based on the research results, it can be concluded that the variable brand trust and brand image have a simultaneous and partial influence on the variable of the decision to choose University in Garut Regency. Then the variable that had the greatest influence on the decision to choose a campus in Garut Regency was the brand image variable followed by the brand trust variable.

\section{REFERENCES}

Desy, E. (2016). Pengaruh Brand Image, Lokasi Dan Fasilitas Terhadap Keputusan Mahasiswa Memilih Universitas Pancabudi (Studi Kasus Mahasiswa Fakultas Ekonomi). Jurnal IImiah "DUNIA ILMU," 2(No. 1 Maret).

Ferrinadewi, E. (2008). Merek dan Psikologi Konsumen Implikasi pada Strategi Pemasaran. Edisi pertama. Graha IImu.

Fianto, A. Y. A. (2014). The Influence of Brand Image on Purchase Behaviour Through Brand Trust. Business Management and Strategy, 5(2), 66-71.

Keller, K. (2003). Strategic Brand Management, Building Measurement and Managing Brand Equity. Person Education Internasional.

Kotler, P., \& Keller, K. L. (2012). Marketing Management. 3rd Edition. Pearson Prentice Hall, Inc.

Lau, G. T., \& Lee, S. H. (1999). Consumers Trust in a Brand and the Link to Brand Loyalty. Journal of Market Focused Management.

Neupane, R. (2015). The Effect of 
Brand Image on Costumer Satisfaction and Loyalti Intention in Retail Supermarket Chain UK. International Journal of Social Science and Management (IJSSM), 2(1), 9-26. doi: 10.3126/ijssm.v2i1.11814

Pertiwi, R., Djawahir, A., Helmy, A., \& Andarwati. (2017). Pengaruh Brand Experience Terhadap Brand Satisfaction, Brand Trust Dan Brand Loyalty (Studi Pada Konsumen Make-Up Brand Impor di Surabaya). Jurnal Manajemen Dan Kewirausahaan, 5(2), 20-25.

Peter, P., \& Olson, J. C. (2010). Consumer Behavior \& Marketing Strategy, Ninth Edition. McGraw Hill.

Rahmawati, D. (2013). Analisis FaktorFaktor yang Mempengaruhi Kepuasan Mahasiswa. Jurnal Economia, 9(Nomor 1, April 2013).

Rangkuti, F. (2013). Strategi Promosi yang Kreatif dan Analisis Kasus. PT Gramedia Pustaka Utama.

Reinartz, W., Krafft, M., \& Hoyer, W. D. (2004). The customer relationship management process: Its measurement and impact on performance. Journal of Marketing Research, 41, 293305.

doi:10.1509/jmkr.41.3.293.35991

Russel, J. T., \& Lane, W. R. (1996). Kleppner's Advertising Procedure, Thirteenth Edition. Prentice Hall.

Saladin, D. (2006). Manajemen Pemasaran. Edisi Keempat. Linda Karya. https://doi.org/10.1016/j.ecss.201 8.10.011

Santoso, S. (2010). Statistik Multivariat. PT Elex Media Komputindo.

Setiadi, N. (2013). Perilaku Konsumen. Edisi Revisi. Kencana.

Singarimbun, M., \& Effendi, S. (1989). Metode Penelitian Survai. PT Pustaka LP3ES Indonesia. https://doi.org/10.1038/s41467019-13294-z
Sugiyono. (2013). Metode Penelitian Kuantitatif, Kualitatif dan $R \& D$. Alfabeta.CV.

Xian, G. L., Xia, W., \& Yu, J. C. (2011). Corporate Product and User Image Dimensions and Purchase Intention. Journal of Computers, 6(9), 1875-1879. 